Reprod. Nutr. Dévelop., 1984, 24 (1), 53-61.

\title{
Effects of age and diet on plasma lipid and glucose concentrations in genetically lean or fat chickens
}

\author{
B. LECLERCQ, D. HERMIER, M. R. SALICHON
}

Station de Recherches avicoles, I.N.R.A., Nouzilly, 37380 Monnaie, France.

\begin{abstract}
Summary. Three experiments were carried out to compare plasma lipid and glucose concentrations in genetically lean (LL) and fat (FL) male chickens. The fat birds always displayed lower glycemia than the lean ones, irrespective of the diet (low-fat or fatty) and nutritional state (fed or fasted). Conversely, triglyceridemia was higher in the fat than in the lean line, particularly in the fed condition. This difference was more pronounced in the birds fed on a low-fat diet and became still more marked as they aged. No consistent differences were found between the two lines as to cholesterolemia and non-esterified fatty acid concentrations.

Injections of Triton WR 1339 increased triglyceridemia ; this effect tended to be more pronounced in the fat birds. The rate of increase of triglyceridemia did not plateau as the dose of Triton increased. The injection of Triton frequently led to convulsions and death. It is concluded that this model of genetic fatness is different from the monogenic models of mammalian obesity since hypertriglyceridemia was not systematic and was not associated with hyperglycemia or hyperinsulinemia.
\end{abstract}

\section{Introduction.}

By selecting broilers for high or low levels of abdominal fat, we have produced two genetically diverse lines of fowl : a fat line (FL) and lean line (LL). These lines exhibit similar live body weights (Leclercq et al., 1980), slightly different food consumption (Touchburn et al., 1981) and different plasma insulin after a meal or a glucose load (Touchburn et al., 1981 ; Simon and Leclercq, 1982). Most of the differences between these experimental lines have been reviewed recently (Simon and Leclercq, 1982). The aim of the experiments described here was to determine if various plasma parameters, and particularly plasma lipid levels, differed between the fat and lean lines.

One characteristic of most mammalian obesities is an elevation of plasma lipid concentrations (Zucker and Zucker, 1962 ; York, 1975). These increased lipid concentrations are mainly due to increased liver synthesis and secretion of triglycerides in the form of very low density lipoproteins (VLDL) (York, 1975) ; these increases are believed to arise as a consequence of high levels of insulin 
secretion in obese mammals. The aim of the present study was to seek to determine similarities or differences between the polygenic model of fatness in the chick and models of mammalian obesity by examining various aspects of lipid transport in the chicken.

\section{Material and methods.}

Three experiments were carried out.

In experiment 1, twenty-four F4 generation male chicks from each line were brooded in individual cages located in a temperature-controlled room maintained at $25{ }^{\circ} \mathrm{C}$. Between 15 and 35 days of age, the chicks were fed on a diet consisting of corn $(57 \%)$, soybean meal $(36 \%)$, corn oil $(3 \%)$, methionine $(1.2 \mathrm{~g} / \mathrm{kg})$, minerals and vitamins. At 35 days of age, 12 chicks from each line were fasted for $15 \mathrm{~h}$; at the end of this period, $5 \mathrm{ml}$ of blood were taken from each bird. The remaining 12 chicks from each line were fasted for $15 \mathrm{~h}$, then allowed to feed for $5 \mathrm{~h}$. At the end of this $5-\mathrm{h}$ feeding period, $5 \mathrm{ml}$ of blood were taken from each animal.

In experiment 2, forty F7 generation male chicks from each of the two lines were used. Each group of 40 chicks was subdivided into 4 groups of 10 each, and each group was housed in a common cage. Two groups from each line were fed on a low-fat diet consisting or corn $(60 \%)$, corn starch $(14 \%)$, soyabean meal $(10 \%)$ and soyabean protein $(12 \%)$, vitamins and minerals. The remaining two groups from each line were fed a " fatty » diet consisting of corn $(60 \%)$, soyabean meal $(10 \%)$, soyabean proteins $(12 \%)$, tallow $(5 \%)$, corn oil $(1 \%)$, vitamins and minerals. Blood samples were collected at 14, 35 and 56 days of age in the starved state and at 16,37 and 58 days in the fed state.

In experiment 3, twenty F6 generation male chicks from each of the two lines were raised in individual cages. They were fed on a low-fat diet containing corn $(25 \%)$, corn starch $(37 \%)$, glucose $(10 \%)$, cellulose $(2 \%)$, soyabean proteins $(16 \%)$, corn gluten $(5.4 \%)$, vitamins and minerals. At 50 days of age fed birds were injected (without anaesthesia) with $1 \mathrm{ml}$ of a saline solution of Triton WR 1339. The amount of Triton injected varied from 25 to $100 \mathrm{mg}$ per $100 \mathrm{~g}$ of body weight. Blood samples were taken just before or $90 \mathrm{~min}$ after injection.

Plasma analysis: blood samples, collected with heparinized syringes and stored at $0^{\circ} \mathrm{C}$ immediately after collection, were centrifuged and the plasma collected. The plasma was stored at $-20^{\circ} \mathrm{C}$ until assay.

In experiment 1, the concentrations of glucose, non-esterified fatty acids, triglycerides, phospholipids and free and esterified cholesterol were measured. Glucose concentrations were measured by the glucose oxidase technique using a Beckman analyser (model 2). Non-esterified fatty acid concentrations were measured in two ways : by a semi-automatic colorimetric method (Fruchart et al., 1974) and by thin-layer chromatography combined with flame ionization detection (TLC-FID) using latroscan TH 10. Triglyceride, phospholipid and free and esterified cholesterol concentrations were determined/by TLC-FID using 
dodecanol as an internal standard. Total cholesterol concentrations were measured by an enzymatic method using a Beckman analyser (model 2). In experiments 2 and 3 , triglyceride concentrations were determined by an enzymatic method using a Technicon auto-analyser (model 2 ).

\section{Results.}

Experiment 1. - The mean ( \pm SDM) concentrations of glucose and lipids in the plasma of fed and starved birds are shown on table 1. The glycemia of LL birds was always higher than that of FL birds, and the glycemia of fed birds was always higher than that of starved birds. There was no significant difference between the two nutritional states as to the concentrations of the various lipid classes measured, except as concerned triglycerides and non-esterified fatty acids (NEFA). Starvation significantly increased NEFA concentration in both lines, and there was no difference in this effect between the two lines. Triglyceridemia was higher in fed than in starved birds, and there was a consistent, although nonsignificant, tendency for higher triglyceridemia in FL than in LL birds, irrespective of their nutritional state.
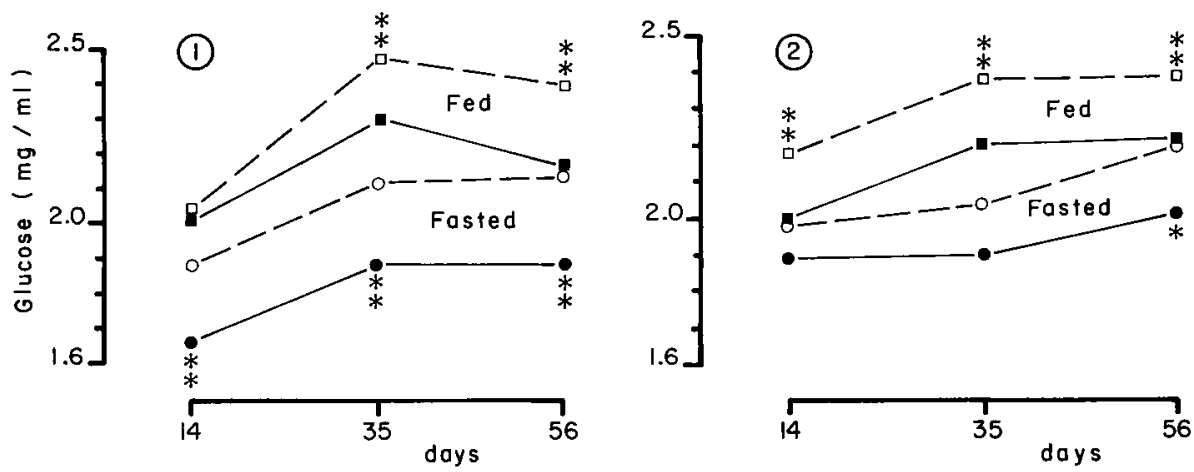

FIG. 1. - Glycemia of fed or fasted, Jean or fat ma/e chickens fed on a low-fat diet (experiment 2).

- : fasted FL ; $\bigcirc$ : fasted LL ; $\square$ : fed FL ; $\square$ : fed LL.

* : significant difference at $5 \%$ level ; ** significant difference at $1 \%$ level.

FIG. 2. - Glycemia of fed or fasted, lean or fat male chickens fed a fatty diet (experiment 2). See legend of figure 1.

Experiment 2. - Age variations in glycemia in birds fed on the low-fat diet are shown on figure 1. The glycemias of the starved birds differed greatly, depending on the genetic origin of the animals. The FL chicks always displayed lower glycemia, and the same was true for fed birds; at 14 days of age, the differences between the FL and LL lines was not significant.

The glycemia of chicks fed on the fatty diet is shown on figure 2. Variations and differences similar to those found for the birds fed on the low-fat diet were observed, but between-line differences were less pronounced. 


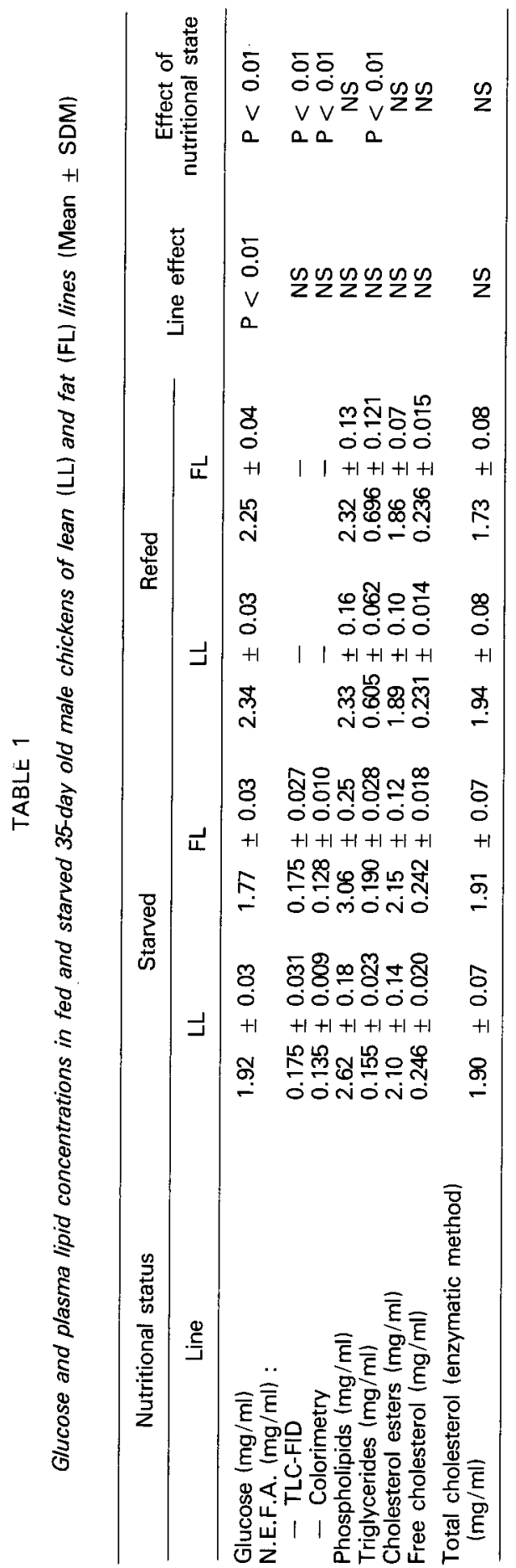


Triglyceridemia according to age, line and nutritional state of chicks fed on the low-fat diet is shown on figure 3. In fasted chicks, the triglyceridemia of FL birds was always higher than that of LL birds ; at 35 days of age the difference was significant at the $10 \%$ level and at 56 days old it was significant at the $5 \%$ level. In fed chicks, triglyceridemia was not significantly different between lines at 14 days old, but the two lines became progressively more divergent as the chicks aged. Age variations in triglyceridemia in chicks fed on the fatty diet are shown on figure 4. In fasted birds there was no significant difference between lines at any age. In fed birds, however, there was a significant difference at 35 days old.
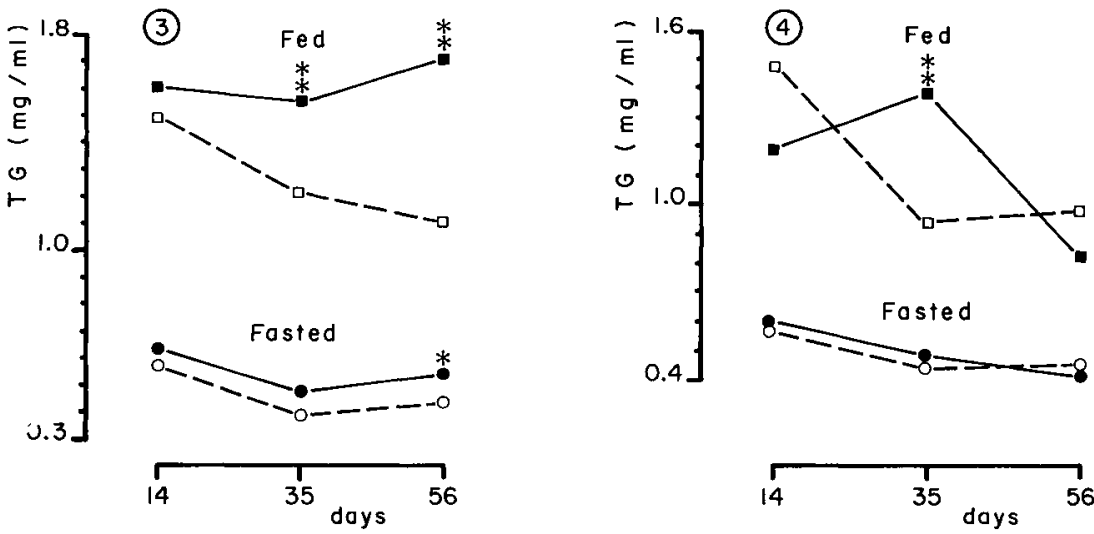

FIG. 3. - Triglyceridemia of fed or fasted, lean or fat male chickens fed a low-fat diet (experiment 2). See legend of figure 1.

FIG. 4. - Triglyceridemia of fed or fasted, lean or fat male chickens fed a fatty diet (experiment 2). See legend of figure 1.

The total cholesterolemia of birds fed on the low-fat diet is shown on figure 5. In fed birds, plasma cholesterol was higher in the FL than in the LL only at 56 days of age. In fasted birds there was no significant difference between lines, except at 14 days old when LL chicks exhibited higher plasma cholesterol. The total cholesterolemia of birds fed the fatty diet is shown on figure 6 . No significant differences were found at any age between'lines. Moreover, the chicks fed on the fatty diet frequently displayed lower cholesterolemia than those fed on the low-fat diet. This observation was true in both lines.

Experiment 3. - The relationship between triglyceridemia and the amount of Triton WR 1339 injected is illustrated on figure 7. Significant increases in triglyceridemia were induced $90 \mathrm{~min}$ after Triton injection.

However, under the conditions described here, triglyceridemia did not plateau as the dose of Triton increased. The highest doses of Triton used here were similar to the highest doses used in experiments on mammals. The regression lines of triglyceridemia on the amount of Triton injected in the FL and LL birds, respectively, were not significantly different. However, the $F$ value 
obtained from covariance analysis was 2.45 which is nearly significant. In this experiment, many cardiac and respiratory accidents were observed after the injection of Triton solution, even at the lowest concentration.
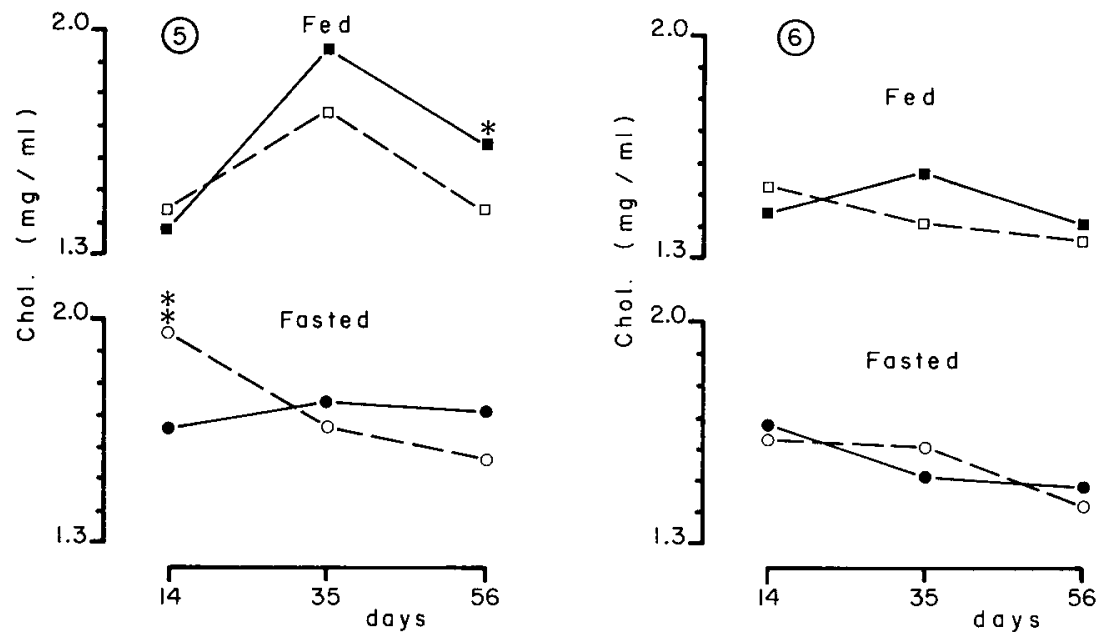

FIG. 5. - Total cholesterolemia of fed or fasted, lean or fat male chickens fed a low-fat diet (experiment 2). See legend of figure 1.

FIG. 6. - Total cholesterolemia of fed or fasted, lean or fat male chickens fed a fatty diet (experiment 2). See legend on figure 1.

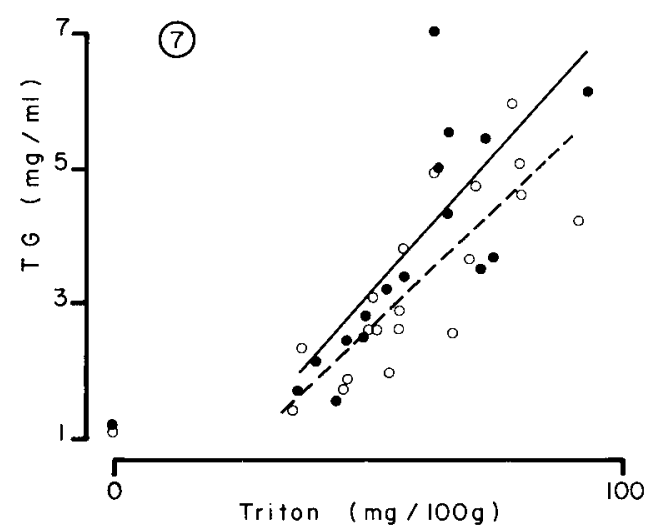

FIG. 7. - Influence of intravenous injection of Triton WR 1339 on triglyceridemia of 50-day old fed male chickens (experiment 3 ).

O : LL ; • : FL.

The correlation coefficients between triglyceridemia and the dose of Triton WR 1339 injected were 0.66 and 0.88 for the FL and LL chickens, respectively. 


\section{Discussion.}

Most mammalian obesities are associated with hyperglycemia, hypertriglyceridemia and hypercholesterolemia (Mayer and Jones, 1953 ; Zucker and Zucker, 1962 ; York, 1975 ; Kaplan and Leveille, 1976 ; Mahler et al., 1976 ; Bach et al., 1981). Higher lipoproteinlipase activity is also very frequently associated with these obesities (Gruen et al., 1978 ; Hartman, 1981 ; McNamara and Martin, 1982). It has been extensively demonstrated that monogenic ( $\mathrm{fa} / \mathrm{fa}$ rats) and polygenic (mainly human) obesities are due to high triglyceride synthesis in the liver and the adipose tissue (Jansen et al., 1967 ; Robertson et al., 1973 ; York, 1975 ; Jeanrenaud et al., 1977). This enhanced lipogenesis and lipoproteinlipase activity are thought to be the consequences of hyperinsulinemia (Dubuc, 1976 ; Borensztajn et al., 1972 ; Garfinkel et al., 1976).

In our polygenic model of fatness in the chicken no true obesity was observed since total lipids did not exceed $20 \%$ of body weight (Simon and Leclercq, 1982). However, some significant interline differences in plasma parameters appeared very early in the selection program. In the F3 generation, we showed that there was a difference in glycemia in fasted and in fed FL chicks shortly after hatching (Touchburn et al., 1981); by the F5 generation, this difference could be detected before hatching (Simon and Leclercq, 1982). As in the fa/fa rat (Boulange et al., 1981), differences in triglyceridemia between fat and lean chicks were observed very early in life. In the fed state, this difference increased with age, particularly if the chicks were fed on a low-fat diet. The phenomenon was not as clear-cut when the diet contained $6 \%$ added fat. This latter observation is in good agreement with those of Whitehead and Griffin (1982) who showed that the selection of broilers for fatness and leaness on the basis of high and low plasma triglyceride concentrations was more efficient when the birds were fed on a low-fat diet. A higher (although not significant) level of plasma phospholipids was found in the fat birds, implying a higher HDL concentration, as observed in some other obesities (Zucker and Zucker, 1962; Bach et al., 1981). This hypothesis has been confirmed by Hermier et al., (unpublished data) who found higher concentrations of triglycerides and phospholipids in the FL associated with higher concentrations of VLDL and HDL.

The higher triglyceridemia of the fat chickens suggests increased splanchnic secretion of VLDL triglycerides; however, the results of experiment 3 failed to confirm this. In that experiment we used Triton WR 1339, a non-ionic detergent which decreases the removal rate of circulating VLDL in rats (Otway and Robinson, 1967). For unknown reasons, the chicks were unable to tolerate Triton WR 1339, and its injection was frequently followed by convulsions. As in mammals (Fiser et al., 1974 ; Palmer et al., 1978 ; Boulange et al., 1981), triglyceridemia increased markedly and as a linear function of the injected detergent dose. We did not observe a plateau in the response. This could be due either to higher hepatic synthesis of VLDL in birds compared to mammals or the structure of VLDL. In our conditions, VLDL secretion tended to be higher in FL than in LL chickens, but the difference was not significant. The secretion rate of VLDL in FL and LL will be compared in other more physiological conditions. 
In conclusion, systematic differences in glycemia and triglyceridemia were observed between FL and LL chickens. A less pronounced difference was observed in plasma phospholipid concentration. There were no differences between the lines in regard to the other parameters measured, such as cholesterol and non-esterified fatty acids. The differences were generally of a lesser magnitude than those found in monogenic rodent obesities. Some of our results are even in direct contradiction to these models since the FL chicken always displays a lower plasma glucose concentration and does not present permanent hyperinsulemia (Simon and Leclercq, 1982). Our fat line chicken resembles the young pre-obese rat but never develops true obesity with hyperglycemia and insulin resistance. More work is required to elucidate this peculiarity.

Reçu en mai 1983,

Accepté en septembre 1983.

Résumé. Influence de l'âge et du régime sur les teneurs plasmatiques de lipides et de glucose chez des poulets génétiquement maigres ou gras.

Au cours de trois expériences, nous avons comparé les teneurs plasmatiques de glucose, triglycérides, phospholipides, acides gras non estérifiés et cholestérol chez des poulets mâles issus de deux lignées sélectionnées de façon divergente sur le rapport gras abdominal/poids vif. A jeûn comme à l'état nourri, la triglycéridémie est en général plus élevée chez les poulets génétiquement gras. Cette différence s'accuse avec l'âge en particulier si les animaux reçoivent un aliment pauvre en matières grasses. La glycémie des poulets gras est toujours inférieure à celle des poulets maigres quel que soit l'âge et le stade d'alimentation. Des différences moins nettes et moins systématiques peuvent être enregistrées pour le cholestérol et les phospholipides.

Au cours de la dernière expérience, nous observons que la triglycéridémie s'élève sous l'effet d'une injection de Triton WR 1339 sans que l'on puisse atteindre un plateau de réponse à la dose de Triton injectée. De nombreux cas de mort ou de convulsions sont observés à cette occasion laissant soupçonner une plus grande sensibilité du poulet. La différence de réponse des deux lignées est proche du seuil de signification de $5 \%$.

Les poulets de lignée grasse présentent des caractéristiques métaboliques qui ressemblent à celles du raton Zucker pré-obèse. Cependant, chez le poulet, on n'observe jamais d'évolution vers l'obésité vraie accompagnée de diabète et de résistance à l'insuline.

\section{References}

ALBRINK M. J., KRAUSS R. M., LINDGREN F. T., VON DER GROEBEN J., PAN S., WOOD P. D., 1980. Intercorrelations among plasma high density lipoprotein, obesity and triglycerides in a normal population. Lipids, 15, 668-676.

BACH A., BOULANGE A., SCHIRARDIN H., de GASOUET P., 1981. Phenotypic variability in unweaned 3 week old Zucker rats. Reprod. Nutr. Dévelop., 21, 929-936.

BORENSZTAJN J., SAMOLS D. R., RUBINSTEIN A. H., 1972. Effect of insulin on lipoprotein lipase activity in the rat heart and adipose tissue. Am. J. Physiol., 223, 1271-1275.

BOULANGE A., PLANCHE E., de GASOUET P., 1981. Onset and development of hypertriglyceridemia in the Zucker rat (fa/fa). Metabolism, 30, 1045-1051.

DUBUC P. U., 1976. The development of obesity hyperinsulinemia and hyperglycemia in ob/ob mice. Metabolism, 25, 1567-1580.

FISER R. H., DENNISTON J. C., RINDSIC R. B., BEISEL W. R., 1974. Triglyceride secretion rates : use of Triton WR 1339 in the rhesus monkey. J. Nutr., 104, 223-226. 
FRUCHART J. C., DEWAILLY P., JAILLARD J., SEZILLE G., 1974. Dosage colorimétrique semiautomatique des acides gras. Ann. Biol. clin., 32, 237-244.

GARFINKEL A. S., NILSSON-EHLE P., SCHOTZ M. C., 1976. Regulation of lipoprotein lipase induction by insulin. Biochim. biophys. Acta, 424, 264-273.

GRUEN R., HIETANEN E., GREEWOOD M. R. C., 1978. Increased adipose tissue lipoprotein lipase activity during development of the genetically obese rat. Metabolism, 27, 1955-1966.

HARTMAN A. D., 1981. Lipoprotein lipase activity in adipose tissues and muscle in the obese Zucker rat. Am. J. Physiol, 241, E108-E115.

JANSEN G. R., ZANETTI M. E., HUTCHINSON C. F., 1967. Studies on lipogenesis in vivo. Fatty acid and cholesterol synthesis in hyperglycemic obese mice. Biochem. J., 102, 870-877.

JEANRENAUD B., FREYCHET P., ASSIMACOPOULOS F., LEMARCHAND Y., KARAKASH C., 1977. Regulation of liver lipid metabolism in experimental obesity. Biochem. Soc. Trans., 5, 890-894.

KAPLAN M. L., LEVEILLE G. A., 1976. Caloric response in obese and non-obese women. Am. J. clin. Nutr., 29, 1108-1113.

LECLERCO B., BLUM J. C., BOYER J. P., 1980. Selecting broiler for low or high abdominal fat : initial observations. Br. Poult. Sci, 21, 107-113.

MAHLER R. J., DUBUC P. U., MOBLEY P. W., ENSINCK J. W., 1976. Glucagon and insulin relationship in the obese hyperglycemic mouse (ob/ob). Horm. Met. Res., 8, 79-80.

MAYER J., JONES A. K., 1953. Hypercholesterolemia in the hereditary obese hyperglycemic syndrome of mice. Am. J. Physiol., 175, 339-342.

McNAMARA J. P., MARTIN R. J., 1982. Muscle and adipose tissue lipoprotein lipase in fetal and neonatal swine as affected by genetic selection for high or low back fat. J. anim. Sci., 55, 1057-1061.

OTWAY S., ROBINSON D. S., 1967. The effect of a non-ionic detergent (Triton WR 1339) on the removal of triglyceride fatty acids from the blood of the rat. J. Physiol., 170, 309-319.

PALMER J. F., COOPER C., SHIPLEY R. A., 1978. Rate of release of hepatic triacylglycerol into serum in the starved rat. Biochem. J., 172, 219-226.

ROBERTSON R. P., GAVARESKI D. J., HENDERSON J. D., PORTE D., BIERMAN E. L., 1973. Accelerated triglyceride secretion. A metabolic consequence of obesity. J. clin. Invest., 52 , $1620-1626$.

SIMON J., LECLERCQ B., 1982. Longitudinal study of adiposity in chickens selected for high or low abdominal fat content : further evidence of a glucose-insulin imbalance in the fat line. J. Nutr., 112, 1961-1973.

SIMON J., LECLERCQ B., 1983. Relation insuline adiposité dans deux lignées de poulets rendus maigres ou gras par sélection. Reprod. Nutr. Dévelop., 23, 443-451.

TOUCHBURN S. P., SIMON J., LECLERCO B., 1981. Evidence of a glucose-insulin imbalance and effect of dietary protein and energy level in chickens selected for high abdominal fat content. J. Nutr., 111, 325-335.

WHITEHEAD C. C., GRIFFIN H. D., 1982. Plasma lipoprotein concentration as an indicator of fatness in broilers : effect of age and diet. Brit. Poult. Sci., 23, 299-306.

YORK D. A., 1975. Lipid metabolism in genetic models of obesity. Proc. Nutr. Soc., 34, 249-255.

ZUCKER T. F., ZUCKER L. M., 1962. Hereditary obesity in the rat associated with high serum fat and cholesterol. Proc. Soc. exp. Biol. Med., 110, 165-171. 